\title{
CRÔNICA DO DESCALABRO
}

\author{
ROCHA, João Cezar de Castro. Guerra cultural e retórica do ódio, crôni- \\ cas de um Brasil pós-político. Goiânia: Caminhos, 2021.
}

Fábio Ferreira de Almeida ${ }^{1}$

Universidade Federal de Goiás, UFG, Goiânia, GO, Brasil

João Cézar de Castro Rocha decidiu dar-se ao trabalho de se embrenhar nos esgotos do bolsonarismo com o propósito firme de "caracterizar a onda Bolsonaro" que, para ele, é "parte de um movimento mais amplo de reorganização das forças de direita no Brasil, que resultou na ascensão da extrema-direita" (ROCHA, 2021, p. 147). Retornou de lá, segundo depoimentos seus em diversos canais, com inúmeras anotaçóes, cadernos e mais cadernos completamente preenchidos com os registros dessa descida. O resultado é o livro Guerra cultural e retórica do ódio, crônicas de um Brasil pós-político, recém-lançado pela editora goiana Caminhos. Nele, o autor persegue o propósito nada singelo de

\begin{abstract}
caracterizar a mentalidade bolsonarista por meio da guerra cultural, isto é, [estudar] o resgate insensato da Doutrina de Segurança Nacional, o alinhamento cego à matriz narrativa conspiratória do Orvil, a adesão náufraga ao sistema de crenças Olavo de Carvalho e, por fim, a crítica ruidosa a uma imaginária 'ideologia de gênero' como passaporte para a conquista do eleitorado evangélico e conservador (ROCHA, 2021, p. 147, grifos do autor).
\end{abstract}

No Posfácio do livro, o historiador Cláudio Ribeiro nos lembra que compreender o modo de funcionamento específico da sociedade brasileira, interrogando os modelos repetidos como lugares-comuns há décadas, é

\footnotetext{
${ }^{1}$ Fábio Ferreira de Almeida, bacharel e mestre em filosofia pela Universidade Federal de Goiás, doutor em filosofia pela Universidade do Estado do Rio de Janeiro, em co-tutela com a Université de Borgonha (França). Professor da Faculdade de Filosofia da Universidade Federal de Goiás desde 2009 e do Programa de Pós-Graduação em Filosofia nas linhas de Ontologia e Metafísica e Estética e Filosofia da Arte. Temas de interesse: Filosofia Contemporânea, Filosofia Francesa Contemporânea, Epistemologia e História das Ciências, Filosofia e Literatura.
} 
uma preocupação antiga de Castro Rocha. Hoje podemos avaliar, então, o quanto o ano de 2013, com suas manifestaçóes estarrecedoras em mais de um sentido (e estes quase sempre orientados em direçóes divergentes), assim como em tudo o que se seguiu a partir de entáo, deve ter sido estimulante para alguém com esse interesse de reflexão e de pesquisa. Aqueles acontecimentos, deflagrados pela truculência policial contra um movimento que há muito reivindicava a gratuidade da passagem de ônibus em Sáo Paulo e que, naquele momento, protestava contra mais um aumento de tarifa, como que abriram caminho para outros movimentos, menos espontâneos, menos populares, movimentos quase coreografados e, acima de tudo - loi oblige -, pacíficos, que culminaram com a eleição de Jair Bolsonaro, que em 2018 se tornou democraticamente presidente do Brasil. Curiosamente, a convulsão das ruas, essa explosão de uma revolta legitimamente popular que se alastrou pelo país foi, ao fim e ao cabo, o laboratório do movimento que levaria ao poder um dos projetos mais reacionários e autoritários da história da República. Pois o livro de João Cezar de Castro Rocha é sobre os mecanismos que tornaram isso possível.

O autor consegue resgatar elementos subjacentes a estes acontecimentos que nem sempre, ou quase nunca, são percebidos, mas que, na leitura do livro, se mostram como se há décadas gritassem nos ouvidos surdos (ou feitos moucos) de nossos analistas bem-pensantes, reforçando uma das estratégias que o bolsonarismo executa com rigor e eficácia admiráveis: cegar pelo excesso de clareza. Basta prestar atenção à composição ministerial e aos cargos secundários do governo de Jair Bolsonaro, e, especialmente, à presença inabalável de uma figura como a do General Augusto Heleno ${ }^{2}$ à frente do Gabinete de Segurança Institucional para vermos comprovado o resgate da Doutrina de Segurança Nacional, concebida pela Escola Superior de Guerra para travar um combate violento e agressivo contra um imaginário inimigo externo. Basta dar uma olhada nas atitudes e publicaçóes da pessoa nomeada para estar à frete de um ministério como o das Relaçóes Exteriores, e perceberemos o peso da presença do sistema de crenças elaborado por Olavo de Carvalho em um paciente trabalho de trinta anos. Basta ouvir o que contam outros ministros, igualmente inamovíveis de seus cargos, como

${ }^{2}$ Como lembra Rocha (2021), citando o livro Tormenta, de Thaís Oyama, em 1977 o entâo capitão Heleno, que esteve ao lado de Sílvio Frota, "maior expoente da linha dura do regime militar, tentou emparedar o presidente Ernesto Geisel, a quem pretendia suceder e criticava por ser de 'centro-esquerda"' (p. 164, grifo da autora). 
o do Meio Ambiente, da Educação ${ }^{3}$, da Mulher, Família e Igualdade Social ${ }^{4}$, para que se veja em operação a mesma "lógica de Napoleão de hospício", sobre a qual se equilibra um documento tão importante quanto ignorado, o Orvil. Tudo é táo explícito, tudo é escancarado de maneira tão pornográfica, que o livro de Joáo Cézar de Castro Rocha torna-se ainda mais importante: ele nos mostra o que, de tanto ver, já não enxergamos, como se os nervos estivessem distendidos; como se, de tão surrados, já não sentissem, numa espécie de mecanismo de auto-preservação.

Orvil, que é "livro" escrito ao contrário, mimetiza ao revés o livro Brasil nunca mais, no qual estáo compilados documentos sobre as atrocidades cometidas durante o regime militar. O Orvil pretende, assim, mostrar o contrário do que mostra o livro, como se dissesse, ao invés de "Brasil nunca mais", "Brasil acima de tudo"... sempre. É também o que tenta fazer outro livro (outro "orvil"), incensado pelos bolsonaristas e pelo próprio Bolsonaro, cujo título também é de uma assombrosa clareza: espécie de versão tropical de Main Kampf, A verdade sufocada conta a versão reversa do que documentos, depoimento e fatos comprovam de maneira irrevogável, revelando um apego ao avesso e aversão à verdade factual. Seu autor, Carlos Alberto Brilhante Ustra, factualmente confirmado como um dos personagens mais macabros dos poróes da ditadura, apresenta neste livro o país das maravilhas do bolsonarismo. No entanto, essa figura abjeta tem sido pública e impunemente homenageada tanto pelo presidente da República quanto pelo seu vice, o também militar Hamilton Mourão, e pelos três ou quatro filhos de Bolsonaro, que não se constrangem em desfilar, inclusive pelos corredores do Congresso Nacional, vestidos em camiseta negra com os dizeres "Ustra vive!". Tampouco são constrangidos por isso. Se pensarmos na obsessão de Jair Bolsonaro e seu governo por armas (o símbolo da campanha, como mostra a imagem tristemente célebre da capa do livro de Rocha, é a mimetizaçáo de uma pistola com os dedos) e nos

\footnotetext{
${ }^{3}$ Após dois anos de governo, Milton Ribeiro, atual ministro da educação, representa uma espécie de retorno à inépcia sabotadora de Ricardo Vélez, primeiro responsável pela pasta no governo Bolsonaro, indicado por Olavo de Carvalho. Entre o primeiro e o atual, houve Abraham Weintraub, que permaneceu à frente da pasta por mais de um ano, cumprindo a tarefa estratégica de aniquilar as estruturas construídas até então, seguindo à risca o manual olavista.

${ }^{4}$ Pressōes políticas recentes obrigaram o ministro a que nos referimos aqui a pedir demissão do cargo, o que ocorreu em 29 de março de 2021. Atualmente, o noticiário vem reportando uma pressão crescente contra a permanência do ministro do meio-ambiente que, no entanto, se mantém chefe da pasta. Sobre a ministra da Mulher, Família e Igualdade Social, em meio a tamanha tormenta, pouco se tem ouvido falar. $\mathrm{O}$ que náo deixa de ser inquietante.
} 
documentários da produtora de vídeos Brasil Paralelo, podemos dizer que hoje o Brasil é um pais entre armas e orvis...

Com a eleiçáo de Bolsonaro, admitindo uma contabilidade muito genérica, mas nada imaginária, uma surpresa basbaque tomou conta de boa parte da população que não pôde mais dormir direito; também trouxe um contentamento momentâneo a outra parte que, indiferente, continuou dormindo com certa tranquilidade terceirizada; mas, com aquele resultado, um êxtase pletórico invadiu uma terceira parcela da populaçáo que, de táo exultante, tampouco conseguia pregar o olho ${ }^{5}$. Essa divisão geral em terços perdurou por todo primeiro ano desse governo.

No início de 2020 explodiu uma crise sanitária mundial que serviu para revelar aos incautamente tranquilos e aos excitados com a trágica ascensão do bolsonarismo o que pode um "mito". Outro fenômeno curioso então se produziu no metabolismo político do brasileiro: aquele primeiro terço de nós continua insone de preocupação, de revolta e de vergonha; o segundo, ou continua indiferente ou se arranja como pode com sua consciência, convencendo-se de ter sido enganado, com o que preserva certa tranquilidade e, aos solavancos, dorme ainda; já o terceiro terço continua em festa permanente, brandindo narrativas que insistem no inverso dos fatos.

Em suma, desde a eleição de Bolsonaro, passando pela pandemia e por inúmeras crises pontuais, no fundo, nada mudou. $\mathrm{O}$ resultado disso é que dois terços da população brasileira está esgotado enquanto um terço permanece agarrado à mais profunda indiferença. $\mathrm{O}$ que aproxima os insones preocupados dos insones exultantes é, afinal, o cansaço produzido pela falta de sono, pois é nesse ambiente de cansaço e indiferença que grassa o bolsonarismo. Rocha coloca e busca responder à pergunta: o que é isso que nos está acontecendo?

Desde 2013, era preciso buscar entender a amplitude do fenômeno que marcaria aquele ano. E, de fato, de lá para cá esse esforço tem feito correr muita tinta, muito papel e muitos posts Internet afora. O espetáculo grotesco do processo de impeachment de Dilma Rousseff, em 2016, selou o destino deste país que, como ressalta ainda Cláudio Ribeiro em seu posfácio, "nunca deu certo como nação" (p. 286). Naquele momento estava confirmado o êxito do projeto bolsonarista que pavimentaria o caminho de Jair Bolsonaro

${ }^{5} \mathrm{O}$ jornalista reacionário Percival Puggina transborda dessa exaltação em um vídeo divulgado logo após o resultado do segundo turno da eleição de 2018. Disponível em: < https://www. youtube.com/watch?v=kt2cTY4VK_w\&t=102s>. Acesso em 15/02/2021. 
até presidência da República, ficando comprovado que as forças de extremadireita souberam apropriar-se da energia que se liberou com as chamadas “jornadas de 2013".

Ainda assim, até mais ou menos meados de 2018 (a campanha só começaria oficialmente em 16 de agosto daquele ano), muitos, senáo todos os analistas duvidavam da eleição de Bolsonaro. Também pudera. Era inimaginável que um personagem que frequentava apenas, e se tanto, o anedotário dos bastidores mais exóticos da política nacional; que aquela espécie de clown histriônico que se agarrava à garantia constitucional de liberdade de expressão para atentar contra a constituição e contra a liberdade extravasando impropérios, xingamentos e outras ameaças desde que confrontado, no melhor estilo General Newton Cruz, enfim, era até entáo inverossímil que alguém assim pudesse ser democraticamente eleito presidente da República.

No entanto, também era preciso lembrar que em 2014, no rescaldo das manifestaçôes de 2013, esse personagem foi o candidato a deputado federal mais bem votado no estado do Rio de Janeiro. Dois anos depois, um igualmente improvável Donald Trump seria eleito presidente dos Estados Unidos, com promessas pelo menos aparentemente tâo inverossímeis quanto a de construir um muro que separasse o país do México. E, além destes, outros sinais deveriam ter feito soar alguma sirene de alarme. É muito interessante como Rocha persegue as origens e, como outros autores têm feito ultimamente ${ }^{6}$, destrincha a estratégia que, mundo afora, colocou em marcha essa guerra cultural e a eficácia constrangedora da retórica do ódio. O resultado da articulação desses dois fatores é o que o autor chama de "pós-política", da qual seu livro nos oferece uma preciosa caracterização. Com efeito, agora sabemos que não se pode caricaturar esse movimento e muito menos seus epígonos. Bolsonaro foi a versão tristemente brasileira desse fenômeno global.

Um dos argumentos que levava muita gente (inclusive esse resenhista

\footnotetext{
${ }^{6}$ Muitos livros têm sido publicados a respeito desse movimento internacional. Dentre eles, vale a pena destacar Guerra pela eternidade. O retorno do Tradicionalismo e a ascensáo da direita populista, de Benjamin Teitelbaum, com tradução de Cynthia Costa e publicado pela Editora Unicamp em 2020, Os engenheiros do caos, de Giuliano Da Empoli, com tradução de Arnaldo Bloch, publicado pela Editora Vertigo, A máquina do ódio (2019), de Patrícia Campos Mello, publicado pela Companhia das Letras em 2020, além do best-seller Como as democracias morrem, de Steve Levetsky e Daniel Ziblatt, com tradução de Renato Aguilar, publicado pela Zahar Editora em 2018. Mesmo náo sendo propriamente sobre o tema, acrescentaria a essa bibliografia o excelente As leis fundamentais da estupidez humana, de Carlo M. Cipolla, com traduçáo de Edmundo Barreiro, publicado pela Editora Planeta em 2020.
} 
que ora lês) a não acreditar na eleição de Bolsonaro naquele 2018, que nunca acaba, era o fato de que, em sua história de 35 anos, a democracia brasileira parecia já ter dado provas bastantes de maturidade. Depois da elaboraçáo de uma sofisticada constituição e, é certo, um percalço eleitoral no ano seguinte à sua promulgaçáo, já acumulávamos a experiência de outras seis eleiçóes presidenciais, das quais duas foram vencidas pelo projeto neoliberal de um sociólogo doutamente acanhado, duas outras foram vencidas por um ex-operário de esquerda e duas outras por uma mulher, também de esquerda. Claro que depois de amargar vinte anos de ditadura militar e de um passado marcado pelo autoritarismo, pelo patrimonialismo, pelo patriarcalismo e por todo tipo de desigualdade, descontados todos os problemas que são inerentes a qualquer democracia e aqueles específicos ao país, pensávamos ter chegado em 2018 com um saldo positivo. O que, então, justificaria tamanho retrocesso político? Parece ser essa uma das questóes que impulsionam a pesquisa de Rocha, pois a sua arqueologia do fenômeno do bolsonarismo teve justamente que penetrar nessa fina camada de prática política minimamente razoável que encobria uma estrutura social e, principalmente, uma carga psíquica bem mais complexa e sombria. $\mathrm{O}$ saldo, por mais positivo que fosse, ainda náo era suficiente para avalizar a recém-nascida democracia brasileira.

A imagem de uma arqueologia não é elaborada pelo autor dessa "crônica de um Brasil pós-político", mas ela me parece apropriada, pois, como mostra o livro, foi precisamente esse lado mais primitivo de cada um que a estratégia bolsonarista, recorrendo aos meios que estivessem à disposição, foi capaz de desenterrar. E foram 57,8 milhóes de brasileiros que extravasaram, por meio do voto na figura tosca e rasa do capitão; com as eleiçóes de 2018, irrompeu esse lado que a política, a ética, a moral obrigam esconder, reprimir, até quem sabe sufocar. E era justamente isso que permanecia mal disfarçado pelo período em que se exerceu plenamente (ou, antes, minimamente) a democracia no Brasil. Retirada essa camada, vemos que, se as raízes do autoritarismo brasileiro atravessam sua curta história de quinhentos anos ${ }^{7}$, o bolsonarismo se nutre mais diretamente da truculência militarista e da violência institucionalizada que, com o golpe civil-militar de 1964, ganhou livre curso entre nós.

Não é necessário recontar aqui essa história e, nunca será demais ressaltar, é bom jamais esquecê-la. Reforcemos, como já mencionado acima, o que justificou a dissoluçáo do Congresso Nacional e a decretação

${ }^{7}$ Pode ser observado em: SCHWARCZ, Lília Moritz. Sobre o autoritarismo brasileiro. São Paulo: Companhia das Letras, 2019. 
do estado de sítio naquela época que remonta a menos de setenta anos: a justificativa fundamental era um fantasioso temor de que o comunismo invadisse o país, violando lares e acabando com os bons costumes das famílias, desrespeitando a propriedade privada, expropriando fazendas, saqueando fábricas, usinas e até o comércio mais singelo, além, claro, de usurpar da intimidade de cada um a fé em Deus. A doutrina de segurança nacional, da Escola Superior de Guerra, se justifica essencialmente por isto. É certo que a configuração geopolítica dessa época torna essa história bem mais complexa. Outros interesses aí se imiscuíam e orientavam (inclusive com vultosos financiamentos) institutos como o IPES (Instituto de Pesquisa e Estudos Sociais), encarregados de construçóes narrativas que os meios de comunicação se incumbiam; uns por covardia, outros por simples conivência, de disseminar. Rocha retraça muito bem essa história. Combinando esse trabalho de historiador com aquilo que ele chamou de "etnografia textual", ou seja, um esforço em "descrever, da forma a mais acurada [possível], a lógica interna da mentalidade bolsonarista" (p. 17, grifo do autor), ele nos mostra que essa mentalidade foi gestada por esse medo quase atávico e pelas estratégias reativas que ele vem gerando. É a mesma estratégia que se repete hoje, só que, menos institucionalizada e mais capilarizada por meio do que gosto de chamar de "novas estratégias de convencimento".

E é até muito fácil enxergar como isso se dá. Por exemplo, enquanto escrevia essa resenha, fui confrontado com o mecanismo analisado no livro quando uma notificação de nova publicação do Facebook piscou no lado direito da tela do meu computador. Quase mecanicamente, clico no ícone e, não trazendo nada de interessante a tal nova publicação, rolo rapidamente a página. Não tarda, me deparo com uma publicação do perfil de Jair Bolsonaro. Copio e colo abaixo (menos inspirado e mais como uma homenagem à "etnografia textual" de Rocha) o texto da postagem":

- Não é fácil reconstruir um país destruído ao longo de décadas, ainda mais
quando quem deveria ter trabalhado ao nosso lado para levar adiante o
projeto escolhido nas urnas em 2018 decidiu, de forma egoísta, sabotar o
próprio país e o próprio povo, mesmo em meio a uma pandemia.
- Hoje, iniciamos um novo capítulo e temos uma nova oportunidade de

${ }^{8}$ Permito-me remeter ao meu artigo disponível pelo link:<http://ermiracultura.com.br/ colunista/fabio-ferreira-de-almeida/ $>$. Acesso em: 24/04/2021.

${ }^{9}$ Eram, entấo, 22:30 do dia 03 de fevereiro de 2020 e o governo comemorava o êxito com que, com as boas e velhas negociatas, agora apenas mais escrachadas, já que não se tem nada a temer, muito menos a vergonha, colocaram na presidência do poder legislativo (Câmara e Senado) aliados do bolsonarismo. 
trabalhar em conjunto pelo Brasil; colocando o país, e não mais interesses pessoais, no coraçáo de cada decisão tomada; respeitando, acima de tudo, os anseios e as tradiçóes do povo brasileiro.

- Temos tudo o que qualquer país sonha ter: recursos naturais, belezas sem igual e um povo maravilhoso e trabalhador. É preciso apenas coragem para levar adiante as mudanças e os valores que formam a identidade de nossa nação: Soberania, Liberdade, Fé e Família.

- Cabe a nós a consciência do momento histórico. Náo existe nada mais gratificante para um homem do que servir a pátria e deixar um legado para as próximas geraçôes. Embora o caminho seja árduo, sabemos que a honra é feita de sacrifícios. Brasil acima de tudo; Deus acima de todos!

Patriotismo sobrecarregado de ufanismo, obsessão conspiratória, resignaçáo fingida daquele que sabe o que deve ser feito (poupo aqui a metáfora do herói) e apelo religioso - e é importante notar que a combinação destes dois últimos aspectos confere ao bolsonarismo um caráter messiânico ao qual parte significativa da população se mostra ainda sensível -: estes são os ingredientes fundamentais que o bolsonarismo não fez mais que desenterrar e que maneja com espantosa habilidade. E para quê? Apenas para, sem disfarce, sem receio, e, principalmente, sem pudores, fazer concretamente o exato contrário, e nem é preciso dizer que aquilo a que se diz estar destinado a realizar ("levar adiante as mudanças e os valores que formam a identidade de nossa nação"), nada mais é que um grandiloquente flatus vocis. É essa a coragem medonha que caracteriza o bolsonarismo e, de fato, surpreende a eficácia da estratégia ${ }^{10}$. No Brasil, quem ensinou essa estratégia ao bolsonarismo, sendo o primeiro a utilizá-la, foi o protagonista que a etnografia textual de João Cezar de Castro Rocha (e considero esse um dos maiores méritos do livro) soube muito bem identificar. Figura com certo trânsito no cenário cultural brasileiro pelo menos até início dos anos 2000, Olavo de Carvalho é o verdadeiro articulador da "retórica do ódio".

Autor de livros como Astros e símbolos (1985) $)^{11}$ e Astrologia e religiáo $(1986)^{12}$, desde que seu discípulo, Felipe Moura Brasil, aliado ao editor Carlos Andreazza, colocou na boca dos manifestantes uniformizados em verde-amarelo o bordão "O Olavo tem razão", tornou-se comum entre

\footnotetext{
${ }^{10}$ Até esse momento, a publicação havia recebido 163 mil reações positivas ("curtir", "amei" e "força"). Também foi compartilhada 18 mil vezes e recebeu 19 mil comentários, dos quais os dez últimos foram todos positivos.

${ }^{11}$ CARVALHO, O. Astros e símbolos. São Paulo: Nova Estella Editorial, 1985.

${ }^{12}$ CARVAlHO, O. Astrologia e religiáo. São Paulo: Nova Estella Editorial (Coleção Eixo), 1986.
} 
os opositores, do candidato num primeiro momento e do governo logo em seguida, caricaturar o cérebro por trás do bolsonarismo como "astrólogo", "guru", "maluco", etc. A liçáo mais importante do livro Guerra cultural e retórica do ódio é a de que tal atitude revela apenas a perigosíssima ignorância dos opositores sobre quem é o inimigo que pretendem enfrentar. E Rocha mostra que, de fato, não apenas ninguém o conhecia (nem seus livros, nem suas estratégias) mas, pior, todos o menosprezavam. A perversidade da retórica do ódio está naquela mimetização orviliana. Para utilizar um termo da atualidade, a invertida se dá também caricaturando, bem como menosprezando aquele que ataca. Como numa aplicação, que não deixa de ser original, da lei de taliáo, em que a pena mimetiza o crime, o ataque com caricatura é revidado e punido... com caricatura. E o ataque, por óbvio, não tem a mesma eficácia, não tem a mesma adesão e, portanto, não tem o mesmo efeito que a caricatura reativa. Com isso, o bolsonarismo cresce, floresce e frutifica.

Um caso que ilustra maravilhosamente bem essa rigorosa estratégia envolveu a antropóloga Débora Diniz. Reconhecida pela excelência de seu trabalho acadêmico e conhecida por sua atuação em causas humanitárias, Diniz achou de, em uma rede social, desafiar Carvalho a debater com ela sobre o tema do aborto e, ao fazê-lo, cometeu o pecado de caricaturar o personagem: além de chamá-lo de astrólogo, avançou como prova de sua limitação e idiotia o fato de não ter encontrado sequer uma publicação sua registrada na Plataforma Lattes ${ }^{13}$. Com isso, Carvalho deitou e rolou. Disse, em resposta, que havia deixado de ser astrólogo quando Diniz ainda não tinha deixado as fraldas, que ele não perderia tempo em registrar suas inúmeras obras num curriculum Lattes e que não ter nenhum registro na plataforma era um privilégio que o colocava no mesmo patamar de figuras do quilate de um José Guilherme Merquior, de um Otto Maria Carpeaux, de um Mario Ferreira dos Santos, de um Antônio Olinto, isto é, autores de grandes obras e não de "artiguinhos acadêmicos" lidos apenas pela "corriola de militantes", além do que não debateria nem com ela nem com ninguém um tema como aborto, pois seu pensamento se ocupa de coisas mais elevadas que, obviamente, ela não alcança ${ }^{14}$. E tudo isso com o cuidado

\footnotetext{
${ }^{13} \mathrm{~A}$ plataforma Lattes é uma ferramenta do CNPq que uniformiza o registro da produção acadêmica de todos os estudantes, professores e pesquisadores de todas as áreas no Brasil, facilitando não apenas a localização de trabalhos e pessoas, mas também funcionando como ferramenta de mensuração e avaliaçâo da produção acadêmica nacional. É uma dessas inovações que, pelo menos de meu conhecimento, só existe no Brasil.

${ }^{14}$ Não se pode confiscar a razão de Carvalho: o sistema Lattes é apenas uma ferramenta técnica e está longe de aferir competência efetiva, como a comunidade acadêmica inteira também
} 
malandro de manter uma compostura quase impecável, sem proferir um único insulto ou palavrão. Assistindo ao vídeo, quase dá para ouvir vibrar o séquito bolsolavista. ${ }^{15}$

Do mesmo modo que não se deve caricaturar o fenômeno Bolsonaro, nem o bolsonarismo, também é um erro caricaturar o trabalho de Olavo de Carvalho e João Cezar de Rocha, que com boa dose de paciência e admirável abnegação, conseguiu levar seus escritos a sério apesar de tudo. Não fazêlo significaria deixar Carvalho em seu elemento, e aí, como o talento e a inteligência que tampouco se deve deixar de reconhecer à figura, ele propaga a influência de seu eficaz "sistema de crenças" urdido, na certeira caracterização de Castro Rocha, por esse "escritor, metamorfoseado em ativista político no reino encantado do universo digital" (p. 26). Com efeito, "a prosa de Olavo de Carvalho manipula com esperteza uma gama de artifícios que, ao suprimir as mediaçóes entre os pontos discutidos, inviabiliza o pensamento, demandando somente a adesão irrestrita à palavra oracular" (p. 55).

É exatamente isso que Olavo tem feito desde os anos 1990, inclusive sendo um dos pioneiros na utilizaçáo dos meios digitais e da liberdade assustadora que neles fica disponível a qualquer um. Essa influência foi ganhando força e entrou no século XXI arrebatando uma garotada que, em parte, agora, só pode reconhecer tristemente a parvoíce ${ }^{16}$. Mas é preciso continuar atento, pois muitos deles têm voz em grandes jornais e emissoras de TV, muitos inclusive tendo se manifestado a favor do bolsonarismo e do entorno que o alçou ao poder. Dentre estes, além dos já mencionados Felipe Moura Brasil e Carlos Andreazza, encontramos figuras como, entre outros, Pedro Sette-Câmara, Joel Pinheiro da Fonseca, Martim Vasques da Cunha, Alexandre Borges além de Reinaldo Azevedo que, sem a desculpa da ingenuidade juvenil, escreveu uma resenha do livro de Olavo de Carvalho,

reconhece. Ademais, particularmente, não vejo nenhum demérito em ser astrólogo, aliás, muito pelo contrário. Aqui simplifico tanto o desafio lançado por Débora Diniz a Olavo de Carvalho quanto a resposta que este divulgou no vídeo que pode ser acessado pelo link: $<$ https://www. youtube.com/watch?v=jOSGkgKZZ88 >. Acesso em 24/04/2021.

${ }^{15} \mathrm{O}$ professor e psicanalista Christian Dunker cometeu o mesmo equívoco de Diniz: sem desafiá-lo. Dunker critica Olavo de Carvalho, seguindo mais ou menos o mesmo modelo da caricatura no artigo Olavo de Carvalho, o "ideólogo de Bolsonaro", contra o professor Haddad, conforme pode ser consultado em: https://blogdaboitempo.com.br/2018/10/15/olavo-decarvalho-o-ideologo-de-bolsonaro-contra-o-professor-haddad/\# ftn1.Acesso em: 24/04/2021. A resposta veio, dessa vez sem conter a linguagem de calão, em: https://olavodecarvalhofb. wordpress.com/2018/10/17/16-10-2018/. Acesso em: 24/04/2021

${ }^{16}$ Foi o que fez, por exemplo, Martim Vasques da Cunha, no artigo "Tragédia ideológica" (VASQUES CUNHA, M. "Tragédia ideológica”. In: Piauí, agosto/20, no 167, pp. 28-33). 
O mínimo que você precisa saber para não ser um idiota, da qual hoje talvez não se orgulhe. ${ }^{17}$

O "sistema de crenças Olavo de Carvalho" só teve sucesso, porque soube explorar as novas tecnologias de comunicação e as ferramentas digitais com as quais cresceu a geração que o segue (blogueiros, youtubers, influencers, etc.). O propósito dessa utilização do sistema de redes sociais é o de esvaziar o espaço público em que, de algum modo, a imprevisibilidade das trocas e das reaçóes, o diálogo e a ação, se não impedem o surgimento, devem enfraquecer a capacidade de propagação de ímpetos destruidores e autoritários como este.

Nesse sentido, vale a pena ressaltar que o capítulo 1 de Guerra cultural e retórica do ódio, dedicado a analisar o "sistema de crenças Olavo de Carvalho", se inicia com uma análise crítica do filme de Petra Costa, Democracia em vertigem. Para além dos comentários sobre os limites do filme, a referência cinematográfica náo pode deixar de nos remeter a um outro filme que busca refletir sobre a mesma situaçáo que o livro analisa, e que também gerou reaçóes as mais diversas. Bacurau, como que completando uma espécie de trilogia iniciada por Kleber Mendonça Filho com $O$ som ao redor (2012) e Aquarius (2016), fornece uma espécie de radiografia cinematográfica da alma brasileira. $\mathrm{O}$ que me parece que vem ao encontro dessa "crônica de um Brasil pós-político", ensaiada por Rocha, é o início do filme: uma longa sequência em que, ao som da canção Objeto não identificado, de Caetano Veloso, se vê a amplitude estrelada do universo até que um disco voador vai aparecendo na tela em lenta descida para o vilarejo Bacurau, situado em algum lugar do planeta onde a trama se desenrola.

A tecnologia é um aspecto decisivo no filme e a estética Power Rangers dessa descida extraterreste (um disco voador do qual quase se pode ver a linha que o mantém suspenso diante da câmera cada vez que ele retorna na narrativa), que aterroriza os moradores de Bacurau e possibilita aos caçadores de gente organizarem sua diversão macabra que terminará em carnificina, reflete o uso que o bolsonarismo faz do arsenal tecnológico, hoje em dia amplamente disponível. As catárticas cenas em que os moradores do vilarejo eliminam esses caçadores pretensamente todo-poderosos também flertam com a estética de filmes $\mathrm{B}$, contrastando náo apenas com o arsenal tecnológico autêntico dos sofisticados equipamentos de extermínio utilizados pelo bando, mas também com o apuro técnico com que a trama é filmada e do qual o cinema contemporâneo náo pode mais prescindir. Nada

\footnotetext{
${ }^{17} \mathrm{~A}$ resenha foi publicada em 02 de setembro de 2013 na revista Veja.
} 
disso, contudo, serve de fato sem o despudor de recorrer a esses artifícios toscamente concebidos, improvisados com o que se tem à mão no momento. Ora, toda a campanha que elegeu Bolsonaro reflete essa habilidade com que os criadores de Jaspion, Spectremen, Power Rangers e afins seduziram toda uma geraçáo de crianças e jovens, que são hoje os mesmos que dirigem organizaçôes como Revoltados On-Line, MBL e Vem Pra Rua, que estão por trás da produtora Brasil Paralelo, e que foram fisgados e mobilizados pelos livros, pelos Cursos On-line de Filosofia (COF) e pelo programa True Outspeak de Olavo de Carvalho ${ }^{18}$. Uma caricatura risível, uma proposta totalmente inverossímil que tinha até um herói com trejeitos de robô de plástico made in Chine do seu lado, Jair Messias Bolsonaro. Eis o perigo que, de tão evidente, ninguém viu.

Uma das passagens do livro que reflete muito bem esse dispositivo que combina de maneira perigosa os recursos mais elaborados com um uso dos mais precários da tecnologia é quando Rocha (2021, p. 37) nos lembra que:

Na década de 1990, a estratégia de Olavo de Carvalho para combater a hegemonia da esquerda compôs um tríptico. No painel central, a publicação de uma trilogia; nos painéis laterais, de um lado, uma bem-vinda ampliação da bibliografia entâo dominante por meio da divulgaçâo de autores conservadores e liberais; de outro, uma campanha virulenta direcionada estrategicamente contra os principais nomes da esquerda brasileira, que, em geral, ocupavam cátedras na universidade pública. Nessa época, ainda não predominava o fascínio adolescente pelo baixo caláo e a monomania pela obsessão anal que definem os últimos quinze anos da oratória de Olavo de Carvalho (p. 37).

Com efeito, é possível visualizar esse tríptico mal-ajambrado pendurado em um fundo negro sobre a qual despencam, em velocidade alucinante, sequências indecifráveis para qualquer cérebro humano de uns e zeros verdes, um muro intransponível como os que se vê em algumas sequências do filme Matrix. $\mathrm{O}$ que sustenta esse tríptico nessa parede de código binário é apenas a velocidade programada com que as combinaçóes desfilam. Ocorre que quando essa parafernália se encontra com a crueza e com a dureza da vida, quando o universo das redes cruza com o espaço público, ou mesmo com o que resta dele, pode explodir uma reação como aquela que Kleber Mendonça Filho filmou carregando nas tintas que imitam sangue e em explosão de braços e de cabeças: movimentos como Occupy

\footnotetext{
${ }^{18}$ Para comprovar isso, basta ver a entrevista que Alexandre Borges concedeu a Pedro Dória em: <https://www.youtube.com/watch?v=v1CL9seah2U>. Acesso em: 20/04/2021
} 
Wall Steet, aqueles das chamadas primaveras árabes, e outros levantes que ocorreram mundo afora a partir 2010 são, parece-me, dessa natureza. O Brasil de Bolsonaro ainda está atravessando o estágio do massacre imposto pela "lógica de Napoleão de hospício" da "guerra cultural açulada fanaticamente pelo bolsolavismo" (ROCHA, 2021, p. 199).

João Cezar de Castro Rocha não se furta a dar, dos conceitos que elabora, definições precisas. Depois de analisar a "dissonância cognitiva" que tornou possível a criaçáo do alucinado "sistema de crenças" de Olavo de Carvalho, a guerra cultural travada pelo bolsonarismo e a reabilitação high-tech da Doutrina de Segurança Nacional, a viragem à extrema-direita é, desde o título, entendida como a entrada do Brasil em uma era "póspolítica". E o que isso significa? Rocha responde: significa a "recusa da mediaçáo institucional na organização da pólis, ao mesmo tempo em que a política se torna a paixão do dia a dia - paixão sem medida" (ROCHA, 2021, p. 232, grifo do autor). Nesse cenário pós-político, a crítica ao cineasta e ensaísta João Moreira Salles, para quem náo existe bolsonarismo, mas apenas bolsonaristas, me parece das mais pertinentes. "Desentendimento inteligente" (p. 258), fustiga o autor que, a meu ver, incorre logo em seguida em um erro parecido.

Na conclusão de Guerra cultural e retórica do ódio, vemos a metáfora do jogo surgir com o objetivo de preparar uma possível resposta à pergunta que tem tirado o sono de pelo menos um terço da população: o que fazer? "Eis precisamente o que busquei realizar neste livro", escreve Rocha (2021, p. 259): "de um lado, arrumar as peças no tabuleiro bolsonarista, a fim de passar da caricatura para a caracterização da lógica interna do movimento; de outro, propor conceitos que esclareçam o verdadeiro desafio: superar o bolsonarismo e não apenas derrotar Bolsonaro". O que, penso, torna também essa metáfora candidamente inteligente é a não percepção de que as peças não estão desarrumadas no tabuleiro e que o tabuleiro é bolsonarista. E o que isso significa? Significa que as regras, a disposição das peças, as cores das casas, tudo muda ao sabor das circunstâncias e dos interesses exclusivamente bolsonaristas, ou seja, não há arrumação para o "tabuleiro bolsonarista”, pois o jogo é deles, está ganho por eles desde o início, ou seja, a conclusáo precede as premissas, ou, o resultado está dado antes do pontapé inicial. Parece ser também isso a pós-política: como a verdade factual foi substituída pela mentira deslavada (evito a noção à la mode de pós-verdade por desconfiar dela, o que não cabe aqui discutir), já não há mais regras a 
compreender, já não há lógica interna e nem ordem a ser obedecida. Foi o que mostraram as análises do livro, e o que é comprovado pela realidade todos os dias. Superar o bolsonarismo, portanto, será muito mais difícil que derrotar Bolsonaro, muito mais difícil até do que parece acreditar o arguto autor dessa "Crônica do Brasil pós-político".

Esqueçamos as narrativas delirantes, olvidemos as teorias conspiratórias labirínticas, deixemos de rebater as estultices do presidente: só a verdade factual vale o quanto pesa; vale enquanto faz pensar; porque se você parar pra pensar, na verdade, governo Bolsonaro não há. E precisamente porque há bolsonarismo em excesso (p. 265).

Eis a proposta inteligente e bem-intencionada de Rocha, diante da qual se poderia perguntar: será possível isso se admitirmos que vivemos, de fato, em uma era pós-política? Seguindo a lógica militarista e a empáfia de coronel, temo que o bolsonarismo náo hesitaria em parafrasear - cheio de si - certo ministro da educaçáo de tristíssima lembrança e mandaria às favas os fatos, às favas qualquer escrúpulo, especialmente com a verdade factual. E continua o autor: "Lanço os dados numa aposta: exercitar a ética do diálogo, que não vê o outro como um inimigo, porém um outro eu, cuja diferença enriquece minha vida, ao ampliar meu horizonte”. Diante da sensatez dessas palavras, passados mais de dois anos de governo Bolsonaro, a imagem que me ocorre é a seguinte: enquanto lançamos, crédulos, nossos dados, o bolsonarismo olha a mesa com um sorriso assombroso de quem está certo de que o tabuleiro é dele, como quem dissesse: festeje seu par de seis, ele logo será contra você. A pergunta já foi feita antes e, diante da convocação de Rocha para essa "ética do diálogo", vale repeti-la, por mais que pareça não haver resposta evidente para ela: como dialogar com fascistas?

Permito-me concluir dizendo que penso que a situação a que chegamos é bem mais grave. E, como se diz popularmente, não se pode mais dormir no ponto... Num vídeo em que responde às negativas de Universidades e veículos de imprensa em discutir com ele, Olavo de Carvalho retruca: estáo certos, calem a boca e deixem que eu falo ${ }^{19}$. Deixaremos? Novamente, é preciso levá-lo a sério - assim como o bolsonarismo, que só fala e não escuta -, pois o que eles querem é isso apenas: ter razão, ganhar sempre. O livro de Rocha, com a mestria e a honestidade do intelectual autêntico, faz soar a sirene de alarme que, espera-se, não nos deixará dormir de novo. É preciso

\footnotetext{
${ }^{19} \mathrm{O}$ vídeo é indicado por Rocha em algum momento de seu vastamente documentado livro, mas não consegui localizá-lo para indicá-lo aqui, pelo que lamento.
} 
estar alerta e sem cansaço, com o olho vivo e o espírito esperto e, como ao longo de seu livro Rocha parafraseia cançóes dando um sabor especial ao texto, permito-me até dizer: pois náo temos tempo de temer a morte. A democracia tem desses paradoxos. Por aqui, até agora ela nos ofereceu uma tranquilidade pela qual quisemos pagar barato. Isso agora está nos custando caro demais. 